\title{
Phytochemical analysis, antioxidant and anti-inflammatory activity of leaves and bark of Ceropegia rollae Hemadri
}

\author{
Shubhada S Nayak ${ }^{1}$, Nitin A Mirgane ${ }^{2}$, K B Pathade ${ }^{3}$, Vitthal S Shivankar ${ }^{4}$ \& Gurumeet C Wadhawa ${ }^{* 1}$ \\ ${ }^{1}$ Rayat Shikshan Sansthas, Karmaveer Bhaurao Patil College, Vashi, Navi Mumbai, MH, India \\ ${ }^{2}$ SIES College of Arts, Science and Commerce, Sion (West), Mumbai 400 022, MH, India \\ ${ }^{3}$ Maharaja Jivajirao Shinde ASC College, Shrigonda, Dist. Ahmednagar 413 701, MH, India \\ ${ }^{4}$ Rayat Shikshan Sansthas, Chhatrapati Shivaji College, Satara, MH, India \\ *Email: wadhava.gurumeet@gmail.com
}

ARTICLE HISTORY

Received: 13 August 2020

Accepted: 16 October 2020

Available online: 01 July 2021

\section{KEYWORDS}

Ceropegia rollae

Anti-inflammatory activity

Antioxidant activity

FRAP; DPPH

\section{ABSTRACT}

The purpose of the present study is to evaluate in vitro antioxidant activity and anti-inflammatory activity of methanolic extract of the leaves and the bark of the plant Ceropegia rollae Hemadri. The antioxidant activity of the both leaves and bark extract was studied using FRAP and DPPH method. The in vitro anti-inflammatory activity and phytochemical characterization were carried using known protocols. The various phytochemical components such as total phenolics and flavonoids were determined. The plant Ceropegia rollae also contains tannis and ascorbic acid. This is related to the antioxidant activity of the plant Ceropegia rollae extract. The leaves shows good antioxidant and antiinflammatory activity as compared to the bark. These can be used as natural antioxidant and antiinflammatory agents.

\section{Introduction}

Inflammation is an important adaptive rejoinder caused by noxious stimuli and conditions such as tissue injury to the animal. Mostly the oxidative stress and inflammatory establish a complex interaction. The endocellular state shows a key role in the activation and dysfunction of various immune cell (13). Ceropegia rollae Hemadri shows significant radical scavenging activity and also interact with various cell lines (4-6).

Free radicals are highly reactive species; they may have one or more than one unpaired electrons. Such as the superoxide, hydroxyl and peroxy radicals. They may easily attack the cell lines and convert the normal cell into pathogenic cell. These free radicals are responsible for the large nobler of the diseases in the human and the animals. Due to increase in the population and the industrialization, the free radicals are increased in the atmosphere. These free radicals affect the human life badly $(6,7)$. To overcome this, there is need of antioxidants. This antioxidant plays important role for the protection of the body against damage by the radicals. These free radicals are highly reactive. Oxygen radicals are called as ROS and produced by industrial pollution or they are formed by the biochemical process from various cells and the respiratory chain. These free radicals are the main factor for the lipid peroxidation. Ceropegia rollae has certain bioactive compounds, which have good antioxidant and anti-inflammation activities (8-10).

The plant Ceropegia rollae play an important role in inhibition of the various bacterial disorders and overcome the free radical activity and the inflammation. The phytochemicals present in the plant Ceropegia rollae are the tannins, terpenoids, steroids, phenols, cardiac glycosides, saponins, flavonoids, alkaloids and anthraquinones, determined by various protocols developed (11-13). They also give positive test for the flavonoids from the $\mathrm{Mg}-\mathrm{HCl}$ along with the $\mathrm{Zn}-\mathrm{HCl}(14,15)$. The plant also gave Keller and Killani test for the glycosides and with the acetic anhydride and sulphuric acid for the, ferric chloride as reagent test for the phenols $(16,17)$.

Ceropegia rollae is a tuberous herb, which is widespread to Western Ghats and Konkan region of Maharashtra, India. The Stem is pubescent, leaves are ovate, puberulous, cymes in subaxillary and terminal. Flowers are larger, with peduncle and having pedicals hirsute in nature. The flower is 2.3-3.5 cm long, tube with length 1.5-2.5 cm long, base slightly the inflated at all angles. Mostly the flower Petals are 8-16 x 2.8

(C) Nayak et al (2021). This is an open-access article distributed under the terms of the Creative Commons Attribution License, which permits unrestricted use, distribution and reproduction in any medium, provided the original author and source are credited (https://creativecommons.org/licenses/by/4.0/). 
$\mathrm{mm}$, linear, oblong with straight, hairless. (18-21). Flowers are ciliate. They are inner erect, subclavate in nature. Flowering is in the month of AugustSeptember.

There are around 200 species of the Ceropegia, among which 58 species are endemic to the Western Ghats of Maharashtra, India (22).

In the present study, we have used the leaves and the bark of the plant. The bark and leaves shows good anti-inflammatory and anti-oxidant activity.

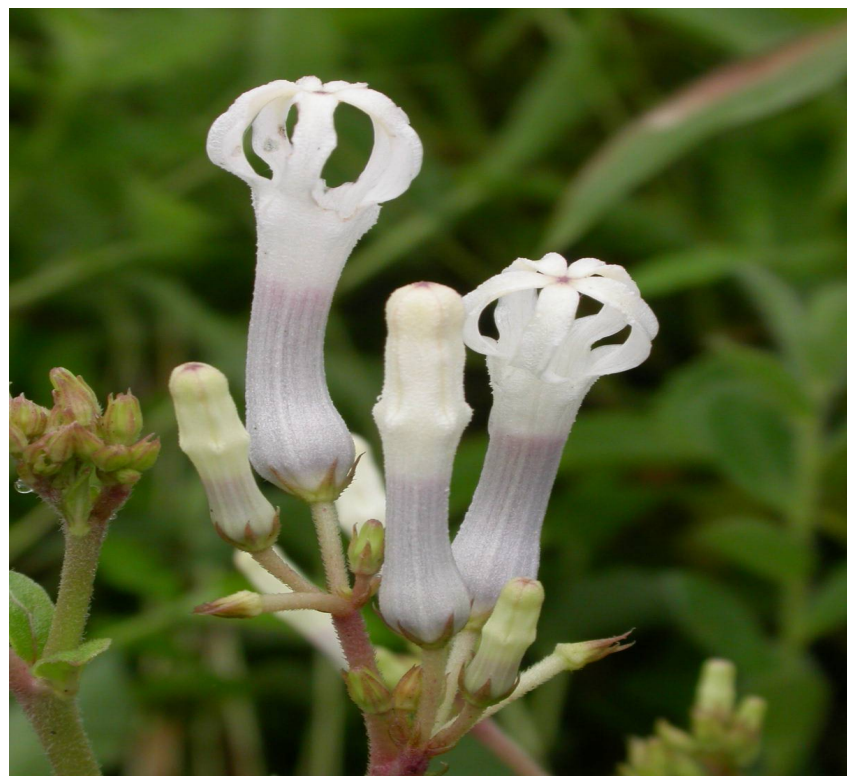

Fig. 1. Flowers of Ceropegia rollae.

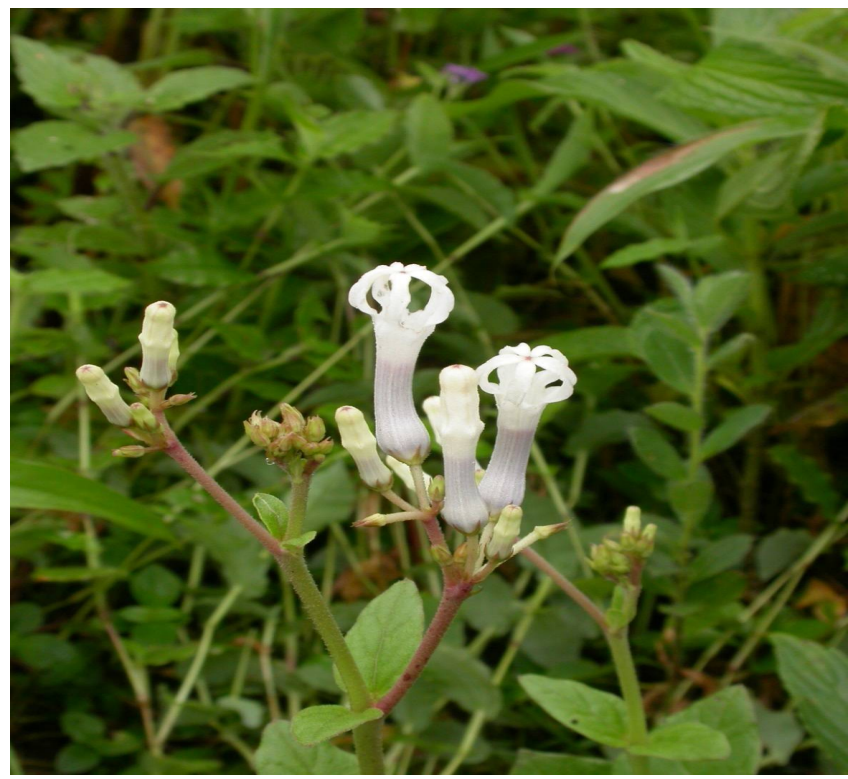

Fig. 2. Leaves with flowers of Ceropegia rollae.

\section{Materials and Methods}

\section{Chemicals and Reagents}

The chemicals used were of analytical grades. All chemicals were purchased from the S.D. Fine and Loba chemicals, Mumbai, India.

\section{Collection of Plant Ceropegia rollae}

The plant Ceropegia rollae was collected from the Rajapur region of the Maharashtra India, identified

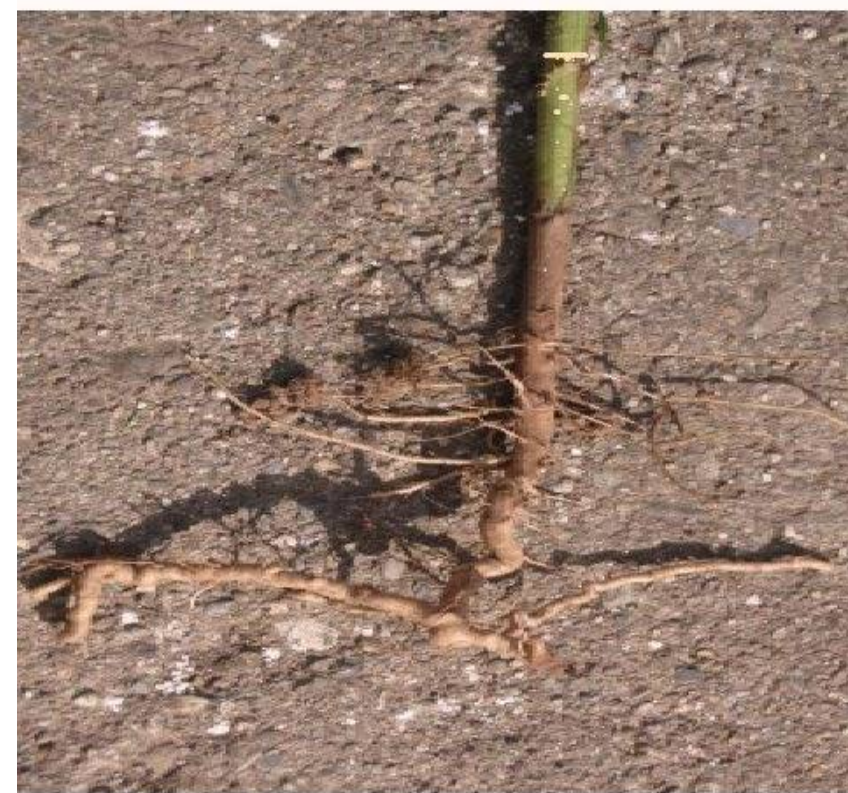

Fig. 3. Roots with bark of Ceropegia rollae.

and authenticated by Dr. Arun Chandore, Abasaheb Marathe College, Rajapur, Tehsil of Ratnagiri District, Maharashtra, India. The specimen was kept in the Abasaheb Marathe College, Rajapur (Fig. 1-3).

\section{Experimental}

The plant material was dried in shade for 4 weeks, then it was dried in oven at $40{ }^{\circ} \mathrm{C}$ for six hrs. Then dried plant material were crushed into fine powder. Both were kept in the glass bottles under inert atmosphere. Phytochemical testing carried out by given protocol and then other biological activity assays were carried using proper protocol.

\section{Determination of total phenolic content}

The total phenol present were determined by the known protocol. This protocol has the extract solution $0.3 \mathrm{ml}$ with $1.5 \mathrm{ml}$ of the reagent, $10 \%$ FolinCiocalteu's then $7.5 \%$ of the sodium carbonate added. The mixture formed at dark for the $30 \mathrm{~min}$. The absorbance was measured at $760 \mathrm{~nm}$ and can be done using the standard gallic acid curve.

\section{Determination of antioxidant activity of the plant Ceropegia rollae}

Antioxidant activity was inspected for the extract by using FRAP and DPPH assays. DPPH is well known standard. The FRAP reagent was prepared with $25 \mathrm{ml}$ acetate buffer with $2.7 \mathrm{ml}$ 2,4,6-tris (2-pyridyl)-Striazine (TPTZ) solution and $2.7 \mathrm{ml}$ of the $20 \mathrm{~mm}$ of ferric chloride water solution. Each sample (150 $\mu \mathrm{l})$ was mixed with $0.6 \mathrm{mg} / \mathrm{ml}$ methanol and $4.7 \mathrm{ml}$ of the FRAP reagent and stirred for $5 \mathrm{~min}$. The absorbance was measured at the $590 \mathrm{~nm}$. The calibration curve method was used to study. The L ascorbic acid was used as standard (22).

\section{DDPH radical assay}

DPPH assay was reported by Liyana-Pathirana and Shahidi in 2005. The DPPH was newly prepared by 27 $\mathrm{mg}$ of the DPPH dissolved in $100 \mathrm{ml}$ of ethanol at -15 ${ }^{0} \mathrm{C}$ before use $160 \mu \mathrm{l}$ of sample was allowed to react with $2840 \mu \mathrm{l}$ of DPPH reagent and $190 \mu \mathrm{l}$ of distilled 
water for $24 \mathrm{hrs}$ in the gloomy condition. The absorbance was measured at $510 \mathrm{~nm}$. The standard bend was linear at 27 to $800 \mu \mathrm{M}$ of vitamin-C absorbance. All determination was carried using the complex of the DPPH radical by the sample, using the standard protocol (23).

\section{$\%$ inhibition=}

[\{Abs control - Abs sample\}/Abs control] $\times 100$.

Where Abs control is the absorbance of the DPPH radical with ethanol,

Abs sample is the absorbance of DPPH radical with sample extract/standard.

Table 1. FRAP for ethanol extract of the leaves and bark

\begin{tabular}{lc}
\hline Extract & FRAP \\
\hline Leaves Ethanol Extract & 850.00 \\
\hline Bark Ethanol Extract & 750.00 \\
\hline Leaves water extract & 1052.00 \\
\hline Bark water Extract & 988.00 \\
\hline Ascorbic Acid (Standard) & 1240.55 \\
\hline BHT (Standard) & 1198.80 \\
\hline
\end{tabular}

We have studied DPPH activity at the various concentration as from the 0.05, 0.1, 0.2, and 0.3.

\section{In-Vitro anti-inflammatory activity}

For this, the albumin denaturation method was followed with modification. This reaction consists of the test extract with the $1 \%$ aqueous solution bovine as albumin fraction. The $\mathrm{pH}$ of this reaction mixture was adjusted at $37{ }^{\circ} \mathrm{C}$. These are incubated at $37{ }^{\circ} \mathrm{C}$ for $20 \mathrm{~min}$, and heated above $50{ }^{\circ} \mathrm{C}$ for $20 \mathrm{~min}$. Then cooled, the turbidity formed in the solution was measured using the spectrophotometer at $660 \mathrm{~nm}$. The percent inhibition of protein as denaturation was intended as follows:

\section{$\%$ inhibition=}

[\{Abs control- Abs sample\}/Abs control] $\times 100$

where Abs control is the absorbance of the DPPH radical with ethanol,

Abs sample is the absorbance of DPPH radical with sample extract/standard (Table 2 and 3 ).

\section{Antioxidant Activity Determination \\ DPPH Scavenging Test}

Quantitative measurement of radical scavenging property.

\section{Determination of Anti-inflammatory Activity}

Study of anti-inflammatory activity through in-vitro models were carried out on leaves and bark extracts by inhibition of the albumin denaturation. This was studied according to Muzushima and Kabayashi with slight modification at the doses of $200 \mathrm{mg} / \mathrm{kg}$ (Table 4 and 5), (9).

\section{Phytochemical Analysis}

The phytochemical analysis was carried for the leaves and bark extracts for saponins, terpenoids, flavonoids, tannins, and phenols using the fixed protocols. The FRAP and antioxidant activities of leaves and bark ethanol extracts were also studied (Table 6).
Table 2. Antioxidant activity of leaves

\begin{tabular}{ccrr}
\hline Extract conc. $\mathbf{~ m g} / \mathbf{m L}$ & BHT & Ethanol & Water \\
\hline 0.05 & 48.30 & 37.60 & 26.53 \\
\hline 0.1 & 49.40 & 42.64 & 34.53 \\
\hline 0.2 & 52.60 & 50.24 & 43.50 \\
\hline 0.3 & 60.80 & 55.12 & 53.00 \\
\hline
\end{tabular}

Table 3. Antioxidant activity of bark

\begin{tabular}{llll}
\hline Extract conc. $\mathbf{~ m g} / \mathbf{m L}$ & BHT & Ethanol & Water \\
\hline 0.05 & 48.30 & 42.70 & 27 \\
\hline 0.1 & 49.40 & 46.30 & 28 \\
\hline 0.2 & 52.60 & 49 & 29 \\
\hline 0.3 & 60.80 & 56 & 32 \\
\hline
\end{tabular}

\section{Results and Discussion}

The present study reports the phytochemistry, antioxidant and the anti-inflammatory activity of the leaves and bark of the plant Ceropegia rollae. The study revealed the presence of the saponins, terpenoids, flavonoids, tannin, phenolin the in leaves and stem of the plant, using the fixed protocols. Mostly the ethanolic extract and water extract were used for the antioxidant activity by the FRAP and the DPPH assays, and showed excellent activity compared with standard drug. Ethanol extract showed the good antioxidant activity than the water extract compared with the standard. The result of the anti-inflammatory study showed the inhibition of albumin denaturation by the bark and leaves of the plant. Ethanol extract of the leaves and stem showed excellent anti-inflammatory activity.

Table 4. Anti-inflammatory activity of leaves

\begin{tabular}{lccc}
\hline $\begin{array}{c}\text { In-vitro Anti- } \\
\text { inflammatory } \\
\text { activity }\end{array}$ & $\begin{array}{c}\text { Dose } \\
\text { (mg / kg) }\end{array}$ & $\begin{array}{c}\text { Absorbance } \\
\text { value } \\
\text { (Mean + SE })\end{array}$ & $\begin{array}{c}\text { Inhibition of } \\
\text { denaturation } \\
\text { (\%) }\end{array}$ \\
\hline Control & $5 \mathrm{mg} / \mathrm{kg}$ & 0.096 & --- \\
\hline $\begin{array}{l}\text { Standard } \\
\text { (Ibuprofen) }\end{array}$ & $100 \mathrm{mg} / \mathrm{kg}$ & 0.20 & 94 \\
\hline Ethanol extract & $200 \mathrm{mg} / \mathrm{kg}$ & 0.18 & 88 \\
\hline Water extract & $200 \mathrm{mg} / \mathrm{kg}$ & 0.16 & 78 \\
\hline
\end{tabular}

Table 5. Anti-inflammatory activity of stem

\begin{tabular}{lccc}
\hline $\begin{array}{c}\text { In-vitro Anti- } \\
\text { inflammatory } \\
\text { activity }\end{array}$ & $\begin{array}{c}\text { Dose } \\
\text { (mg / kg) }\end{array}$ & $\begin{array}{c}\text { Absorbance } \\
\text { value } \\
\text { (Mean + SE ) }\end{array}$ & $\begin{array}{c}\text { Inhibition of } \\
\text { denaturation } \\
\text { (\%) }\end{array}$ \\
\hline Control & $100 \mathrm{mg} / \mathrm{Kg}$ & 0.096 & -- \\
\hline $\begin{array}{l}\text { Standard } \\
\text { (Ibuprofen) }\end{array}$ & $100 \mathrm{mg} / \mathrm{kg}$ & 0.20 & 94 \\
\hline Ethanol extract & $200 \mathrm{mg} / \mathrm{kg}$ & 0.14 & 72 \\
\hline Water extract & $200 \mathrm{mg} / \mathrm{kg}$ & 0.12 & 66 \\
\hline
\end{tabular}

\section{Conclusion}

We have studied the new species, Ceropegia rollae for phytochemistry, anti-inflammatory and the antioxidant activity. This shows the presence of the various phytochemicals in the leaves and root of the plant. The leaves show the excellent antioxidant and anti-inflammatory activity than the bark. We can use these compounds as the natural antioxidant and antiinflammatory agent. 
Table 6. The Phytochemical screening of the plant Ceropegia rollae

\begin{tabular}{lll}
\hline Test & Leaves & Stem \\
\hline Tanin & Negative & Positive \\
\hline Steroid & Positive & Positive \\
\hline Cardio glycosides & Negative & Positive \\
\hline Flavonoids & Positive & Positive \\
\hline Terpenoids & Positive & Positive \\
\hline Alkaloids & Positive & Positive \\
\hline Phenol & Positive & Positive \\
\hline Saponnins & Positive & Positive \\
\hline Anthraquinones & Positive & Positive
\end{tabular}

\section{Acknowledgements}

We are thankful to Principal, Research Promotion and Ethics Committee Rayat Shikshan Sansthas, Satara.

\section{Authors' contributions}

Concept and work plan was supervised by SN and GW. All the analytical experiments were performed by KP and GW. The manuscript writing and statistical calculation were done by GW. Necessary and final corrections were done by NM and VS. All authors have read and approved the final manuscript.

\section{Conflict of interests}

Authors do not have any conflict of interests to declare.

\section{References}

1. Mirgane NA, Shivankar VS, Kotwal SB et al. Waste pericarp of Ananas comosus in green synthesis zinc oxide nanoparticles and their application in waste water treatment. Materials Today: Proceedings. $2020 \quad$ July https://doi.org/10.1016/j.matpr.2020.06.045

2. Mirgane NA, Shivankar VS, Kotwal SB et al., Degradation of dyes using biologically synthesized zinc oxide nanoparticles. Materials Today: $\quad$ Proceedings. 2020 July 9 https://doi.org/10.1016/j.matpr.2020.06.037

3. Patil DD, Mhaske DK, Wadhawa. Antidiabetic activity of bark and root of Caesalpinia bonduc. IJPSR. 2011 Oct 01;2(10):2750-52.

4. Shivankar VS, Wadhawa GC. et al. Phytochemical analysis of the methanol extract from leaves of Hemidesmus indicus. European Journal of Biomedical and Pharmaceutical Sciences. 2016;3(12):539-43.

5. Wadhawa GC et al. Phytochemical analysis of the methanol extract from leaves of Paullinia pinnata. World journal of pharmacy and Pharmaceutical Sciences. 2016, Dec.;5(12):1673-83.

6. Gaikwad YA, Shivankar VS, Wadhawa GC, et al. Antioxidant effect of the root and leaves of solanum melongena Linn. World journal of Pharmacy and Pharmaceutical Sciences. 2016, Dec.; 5(12): 176772 .

7. Wadhawa GC et al. Phytochemical Analysis of the Methanol extract from leaves of Cassia fistula L. Journal of Chemical and Pharmaceutical Research, 2016;8(12):243-47.

8. Dubey S, Ojha K, Chandrakar jagriti, Dehariya R, Vinodia S, Singh A, Dixit AK. Assessment of total phenolic content and antioxidant potentiality of selected Indian folk medicinal plants by spectrophotometric method. Plant Sci. Today. 2020;7(3):383-90. https://doi.org/10.14719/pst.2020.7.3.765

9. Irem $\mathrm{AB}$, Ahmet $\mathrm{CG}$, Hasan $\mathrm{K}$, Erdem $\mathrm{Y}$. Evaluation of the in vitro anti-inflammatory activity of Nerium oleander L. flower extracts and activity-guided isolation of the active constituents,” Records of Natural Products. 2018;12(2):128-41.

10. Harborne JB. Phytochemical Methods Chapman and Hall, London; 1973.

11. Schulz H, Baranska M. Identification and quantification of valuable plant Ceropegia rollae substances by IR and Raman $\begin{array}{lll}\text { spectroscopy. Vibrational Spectroscopy. 2007;43:13-25. } & \end{array}$ https://doi.org/10.1016/j.vibspec.2006.06.001

12. Binet ML, Commereuc S, Chalchat JC, Lacoste J. Oxidation of polyterpenes: a comparison of poly $\alpha$, and poly $\beta$, pinenes behaviours: Part I photo-oxidation. Journal of Photochemistry and Photobiology A: Chemistry. 1999;125:45-53. https://doi.org/10.1016/ S1010-6030(98)00412-2

13. Talaty N, Takáts Z, Cooks RG. Rapid in situ detection of alkaloids in plant Ceropegia rollae tissue under ambient conditions using desorption electrospray ionization. Analyst. 2005;130:1624-33. https://doi.org/10.1039/B511161G

14. Tsuchiya $H$, Hayashi $H$, Sato $M$, Shimizu $H$, Linuma $M$ Quantitative analysis of all types of $\beta$-carboline alkaloids in medicinal plants and dried edible plants by high performance liquid chromatography with selective fluorometric detection. Photochemical analysis. 1999;10:247-53.

15. Liu L, Zhang Y, Tang, S. An efficient system to detect protein ubiquitination by agroinfiltration in Nicotiana benthamiana. The plant journal. 2010;61:893-903. https://doi.org/10.1111/j.1365313X.2009.04109.x

16. Khan AM, Rizwana, Qureshi RA, Ullah F et al. Phytochemica analysis of selected medicinal plants of Margalla Hills and surroundings. Journal of Medicinal Plants Research. 2011;5 6017 23.

17. Khorasani AE, Mat RT, Mohajer S, Banisalam B. Antioxidan activity and total phenolic and flavonoid content of various solvent extracts from in vivo and in vitro grown Trifolium pratense L. (Red clover). Biomed Res Int. 2015;2015:1-11.

18. Ansari MY. Asclepiadaceae: genus- Ceropegia. Fascicles of Flora of India.1984;16:1-34.

19. Chatterjee, S. 1995. Global 'hot spots' of biodiversity. Curr. Sci. 68:1178-79.

20. Dyer RA. Ceropegia, Brachystelma and Riocreuxia in South Africa. 1983.

21. Ceropegia concanensis, a new species (Apocynaceae: Ceropegieae) from Western Ghats, India. Kew Bull. 67:843-48.

22. Tomic JL, Pensalfini A, Head E, Glabe CG. Soluble fibrillar oligomer levels are elevated in Alzheimer's disease brain and correlate with cognitive dysfunction. Neurobiol Dis. 2009;35(3):352-58 https://doi.org/10.1016/j.nbd.2009.05.024

23. Yen GC, Duh PD. Scavenging effect of methanolic extracts of peanut hulls on free-radical and active oxygen species. J Agric Food Chem.1994;42: 629-32.

Additional information

Peer review information: Plant Science Today thanks Sectional Editor and the other anonymous reviewers for their contribution to the peer review of this work.

Reprints and permissions information is available at https://horizonepublishing.com/journals/index.php/PST/open_access_policy

Publisher's Note: Horizon e-Publishing Group remains neutral with regard to jurisdictional claims in published maps and institutional affiliations.

To cite this article: Nayak S S, Mirgane N A, Pathade K B, Shivankar V S, Wadhawa G C. Phytochemical analysis, antioxidant and anti-inflammatory activity of leaves and bark of Ceropegia rollae Hemadri. Plant Science Today. 2021:8(3):425-428. https://doi.org/10.14719/pst.2021.8.3.906

Plant Science Today, published by Horizon e-Publishing Group, is covered by Scopus, Web of Science, BIOSIS Previews, Clarivate Analytics, etc. See https://horizonepublishing.com/journals/index.php/PST/indexing abstracting 